\title{
Društvena evaluacija hrvatskog inovacijskog sustava na primjeru test programa ${ }^{1}$
}

\author{
Jadranka ̌̌varc \\ Institut Ivo Pilar \\ jadranka.svarc@pilar.hr
}

Juraj Perković

Institut Ivo Pilar

juraj.perkovic@pilar.hr

Jasminka Lažnjak

Filozofski fakultet u Zagrebu, Odsjek za sociologiju jlaznjak@ffzg.hr

\begin{abstract}
SAŽETAK Rad prikazuje odabrane rezultate društvene evaluacije Hrvatskog inovacijskog sustava (HIS) koja se temelji na tezi da u Hrvatskoj možemo govoriti o sistemskim neuspjesima inovacijskog sustava koji dovode do zaostajanja u tehnologiji i konkurentnosti. Cilj istraživanja bio je otkriti prepreke u ostvarenju ciljeva prvog inovacijskog programa za potporu tehnologijskim projektima (TEST program) i temeljem tih prepreka zaključiti o sistemskim nedostacima cijelog inovacijskog sustava. Istraživanje je provedeno metodom ankete na uzorku voditelja TEST projekata ispitujući njihove stavove prema nizu dimenzija programa koje čine osnovne komponente društvene evaluacije tog segmenta inovacijske politike. Činjenica je da ne postoje evaluacije koje bi dale procjenu uloge i značenja inovacijskih programa u znanstveno-tehnološkoj politici u ovisnosti o socio-kulturnom okružju i povijesnom naslijeđu, u čemu autori pronalaze motiv za ovakav tip istraživanja. Istraživanjem je ustanovljeno da implementacija TEST-a osim do namjeravanih dovodi i do niza nenamjeravanih i neostvarenih posljedica koje premještaju fokus programa s komercijalizacije istraživanja kao glavnog cilja TEST programa na postizanje znanstvenih rezultata, a koji služe uglavnom potrebama znanstvenika za nastavak znanstvenih projekata. Među glavnim pokretačima neželjenih i neostvarenih učinaka identifici-
\end{abstract}

\footnotetext{
1 Ovaj rad predstavljen je na skupu: Inovacijska kultura i tehnologijski razvoj, Hrvatsko društvo za sustave i BICRO, Zagreb, 22-23. listopada 2009.

Copyright (C) 2011 Institut za društvena istraživanja u Zagrebu - Institute for Social Research in Zagreb Sva prava pridržana - All rights reserved
} 
rani su institucionalni deficiti u formalnim i neformalnim institucijama te u širem socio-ekonomskom okruženju. Zaključuje se da je većina projekata uhvaćena u "retrogradno kolo" koje kreće od znanstvene ideje i nakon pokušaja tehnološke primjene ili komercijalizacije vraća se svojim polazištima - znanstvenoj primjeni. Iako je TEST uveo niz organizacijskih i kulturoloških novina u znanstvenu politi$\mathrm{ku}$, rezultati sugeriraju potrebu temeljitog zaokreta u inovacijskoj politici, od one isključivo temeljene na znanstvenim istraživanjima do one koja polazi od postojećih tehnoloških sposobnosti i potreba poduzeća.

Ključne riječi: inovacijski sustav, Hrvatska, socijalna evaluacija, inovacijska politika, namjeravane i nenamjeravane posljedice.

\section{Uvod}

Ovaj rad prikazuje odabrane rezultate analize Hrvatskog inovacijskog sustava (HIS) u sklopu znanstvenog projekta kojeg financira Ministarstvo znanosti, obrazovanja i športa pod nazivom "Društvena evaluacija hrvatskog inovacijskog sustava u funkciji gospodarstva znanja". Sam projekt polazi od stanovišta da je tranzicija u društvo znanja ovisna, među ostalim, o učinkovitosti nacionalnog inovacijskog sustava i inovacijske politike, te da je njihova evaluacija bitna komponenta upravljanja inovacijama i strateškim razvojem.

Inovacijska politika pojavljuje se u sklopu evolutivne i institucionalne ekonomije 80-ih godina prošloga stoljeća, te s obzirom da nastoji formulirati praktična rješenja i mehanizme za poticanje inovacija kao ključnih faktora gospodarskog razvoja, velikom se brzinom proširuje jednako Europom i Amerikom (Carlsson, 2006.; Sharif, 2006.). Njezina bit sastoji se u strateškoj integraciji relativno neovisnih politika - znanstvene, tehnološke i industrijske - u jedinstvenu politiku gospodarskog razvoja temeljenu na znanju i inovacijama ili, drugim riječima, ona je amalgam znanstvene, industrijske i tehnološke politike (OECD-EUROSTAT, 2005.:15). Možemo stoga reći da je inovacijska politika jedna od najvažnijih javnih politika koje bi trebale pridonijeti bržoj integraciji Hrvatske s Europskom Unijom putem ostvarivanja Lisabonskih ciljeva, povećanja međunarodne konkurentnosti (izvoza) te stvaranja preduvjeta za razvoj gospodarstva znanja (Švarc, 2009.)

Počeci hrvatskog inovacijskog sustava kao smišljene politike državne administracije na tehnološkom razvoju i uključivanju znanstveno-istraživačkih potencijala u gospodarski razvoj započela je 2001. godine pokretanjem programa Hrvatskog inovacijskog i tehnologijskog razvitka (HITRA). Međutim, mnogi pokazatelji govore da dosadašnja inovacijska politika nije uspjela u pokretanju inovacija u Hrvatskoj te razvoju temeljenom na znanju i produktivnoj upotrebi znanstveno-istraživačkih resursa. Međutim, do sada nije provedena i javnosti predstavljena evaluacija postignuća u sklopu HITRA programa i nastavne inovacijske politike, što otvara prostor za kritike učinkovitosti cijelog inovacijskog sustava i može dovesti u pitanje i njegovu svrsishodnost. 
Pri tom valja naglasiti da smisao evaluacije znanstvenih ili inovacijskih politika danas nije u podvrgavanju kritici već u otkrivanje uzroka njihovog slabog funkcioniranja. Danas dolazi do premještanja fokusa evaluacije inovacijskih politika i programa sa sumativne na formativnu ulogu (Rip, 2003.; Guy, 2003.; Perrin, 2002.; Kuhlman, 2003. and 2006.). Dok sumativna uloga obuhvaća procjenu djelotvornosti i učinkovitosti neke politike ili programa pomoću raznih kvantitativnih pokazatelja (performance indicators) kako bi se, primjerice, izvršila financijska kontrola, opravdalo trošenje novca poreznih obveznika, umanjila ili prenamijenila sredstva potpore, formativna evaluacija ima za cilj učenje, prilagođavanje javnih politika specifičnim okolnostima i dugoročno planiranje. Odnos evaluacije i strategijskog razvoja danas se drastično mijenja, jer evaluacija prerasta iz sredstva za mjerenja efikasnosti nekog programa u sredstvo strategijskog razvoja. Do takve promjene uloge evaluacije dolazi zbog kompleksnosti znanstveno-tehnologijskih i inovacijskih politika i programa, te usmjeravanje njihovih ciljeva na postizanje socijalnih i gospodarskih ciljeva kao što je restrukturiranje industrije, otvaranje novih radnih mjesta ili povećanje izvoza. Evaluacija treba dati odgovore na slijedeća pitanja: je li program primjeren određenim okolnostima? Koje su prepreke u njegovom ostvarenju? Kako ga poboljšati i koji su daljnji strateški pravci razvoja (Kuhlmann, 2003.)? Ukratko, formativna evaluacija je proces učenja svih dionika u cilju analize politika i dobivanja povratne informacije za oblikovanje strateških planova razvoja (Kuhlmann, 2003.).

Pri tom, kvantitativni pokazatelji služe kao pomoćno sredstvo za ukazivanje na strukturne ili sistemske društveno-ekonomske barijere u provođenju inovacijskog programa ili ukupne politike.

U svrhu evaluacije hrvatske inovacijske politike formulirali smo metodu socijalne evaluacije koja se temelji jedne strane, na formativnoj evaluaciji kao sredstvu razumijevanja okolnosti koje dovode do ostvarenja ciljeva nekog programa te, s druge strane, na socijalnoj teoriji inovacija koja svoje temelje pronalazi, između ostalog, u novoj inovacijskoj paradigmi (Nelson i Winter 1982.; OECD, 1988.; OECD, 1992.). Prema novoj inovacijskoj paradigmi inovacija je endogena pojava uvjetovana društvenim i institucionalnim kontekstom i predstavlja, u suštini, socijalni proces uvjetovan povijesnim naslijeđem (path dependent), sociokulturnim specifičnostima određene zemlje te institucionalnim okruženjem (Furman et al., 2002.:900; Mytelka i Smith, 2002.:1472). To znači da nacionalni inovacijski kapacitet (Lundvall and Borras, 1997.; Furman et al., 2002.:930) i posljedičan gospodarski rast kroz tehnologijski napredak nisu slučajne pojave određene spontanim djelovanjem tržišta, nego su izraz načina upravljanja i organiziranja raspoloživim resursima koji se reflektira u određenom institucionalnom sklopu - inovacijskom sustavu. Potvrdu ove teze nalazimo već u jednostavnoj činjenici da se zemlje, usprkos dostupnosti gotovo istih potencijala ili resursa u znanosti, gospodarstvu, obrazovanju i sl., uvelike razlikuju po svojoj gospodarskoj razvijenosti i konkurentnosti. Stoga je spori gospodarski razvoj i institucionalni deficit prije rezultat socio-kulturnog i političkog okruženja koje uvjetuje organizaciju znanstveno-tehnologijskih i ekonomskih resursa nego obrnuto. 
U skladu s tim, za uspješnost inovacijskih programa u Hrvatskoj važno razumjeti koji su uzroci "institucionalnog neuspjeha" hrvatskog inovacijskog sustava koji nastaju kao rezultat niza međusobno povezanih fenomena društveno-ekonomskog i političkog karaktera. Stoga socijalna evaluacija može obuhvaćati vrlo raznorodne faktore ekonomskog, kognitivnog, političkog i socio-kulturnog karaktera. Primjerice, među ekonomske faktore možemo svrstati privatizaciju po modelu prazne ljušture - isisavanje supstance poduzeća umjesto njegovog tehnološkog unapređivanja (Županov, 2001.), a među faktore kognitivnog karaktera razumijevanje isključivo neo-klasičnog (science-push) linearnog modela inovacija (znanost je implicitni pokretač razvoja) a zanemarivanje interaktivnog modela inovacija (Kline i Rosenberg, 1986.). U faktore socio-kulturnog karaktera pripada individualni svjetonazor (znanstveni elitizam, paternalizam, nesklonost poduzetničkom riziku i sl.), sustav vrijednosti u društvu (neodgovornost, laka zarada kroz korupciju, burzu i sl.), te konačno u faktore političkog karaktera možemo ubrojiti korupciju koja priječi napredak kroz individualno zalaganje i rad, nekompetentnost i inertnost državne uprave i sl.

Ovo istraživanje nije, naravno, moglo obuhvatiti sve ove kompleksne aspekte funkcioniranja inovacijskog sustava. Ono predstavlja tek pilot istraživanje u socijalno evaluaciji, te se shvaća kao uvod u detaljnije istraživanje, posebice neformalnih institucija.

\section{Inovacijska politika u Hrvatskoj i njena evaluacija}

Ideja o inovacijskoj polici koja nadilazi okvire standardne znanstvene politike kao što je upravljanje znanstvenim projektima i znanstvenim unapređenjima, javlja se u hrvatskoj državnoj upravi sredinom 1990-ih godina, te kulminira pokretanjem prvog programa inovacijske politike - Program hrvatskog inovacijskog tehnologijskog razvitka (HITRA) 2001. godine. HITRA donosi posve nove principe upravljanja znanstvenoistraživačkim potencijalima jer uvodi mehanizme interakcije znanosti i industrije i komercijalne primjene znanstvenih istraživanja, te naglašava potrebu veće uloge znanosti u gospodarskom razvoju² .

\footnotetext{
2 Valja reći da je u doba socijalizma suradnja znanosti i gospodarstva također bila važan dio znanstvene politike, te da su znanstvene organizacije dobar dio svojeg prihoda ostvarivale od suradnje s industrijom. Npr. Institut Ruđer Bošković je 1989. godine 40\% svojih sredstava prihodovao od gospodarstva, a 1999. godine od gospodarstva prihoduje svega oko 13\% (Pisk, 2001.). Međutim, takva je suradnja bila koordinirana i dirigirana od strane države kroz samoupravne interesne zajednice (SIZ) koje se nisu temeljile na tržišnim principima ponude i potražnje i istinskom interesnom udruživanju već su ostvarivale ideju slobodne razmjene rada radnika iz proizvodne i radnika iz društvene sfere garantirane Ustavom SFRJ iz 1974. godine. Stoga je program HITRA nakon kolapsa socijalističkog sustava i u uvjetima devastacije proizvodnog istraživačkog sektora nastojao uvesti institucionalni okvir i sustav potpora koji bi revitalizirao suradnju znanosti i industrije, ali na tržišnim osnovama i međusobnim potrebama.
} 
Takvo usmjerenje proizlazi iz tada prepoznate potrebe da se revitalizira, privatizacijom opustošen, sektor industrijskih istraživanja i da se poveže s javnim sektorom istraživanja kako bi gospodarstvo i stvaranje proizvoda "više dodane vrijednosti" imalo oslonac u domaćim znanstveno-istraživačkim potencijalima U tom su kontekstu opći i dugoročni ciljevi HITRE bili (MZT, 2002.):

- revitalizirati sektor industrijskih istraživanja (devastiran tijekom tranzicije);

- unaprijediti suradnju znanosti i gospodarstva u procesu revitalizacije;

- potaknuti komercijalnu primjenu rezultata istraživanja na znanstvenim ustanovama (prevladati elitizam i dati šansu "rješenjima iz ladice").

Formalno gledajući, Hrvatska danas ima relativno kompleksan inovacijski sustav koji se sastoji od niza znanstvenoistraživačkih ustanova, poslovno-inovacijskih centara, poduzetničkih centra, tehnoloških parkova i sl. U upravljanju inovacijskim sustavom dominiraju dva ministarstva: Ministarstvo znanosti, obrazovanja i športa koje je odgovorno za sektor istraživanja i visokog obrazovanja, te inovacijsku politiku u užem smislu, te Ministarstvo gospodarstva, rada i poduzetništva koje brine o razvitku poduzetničke infrastrukture (razvojne agencije, slobodne zone, inkubacijski centri i sl.) i programima potpore za razvoj malog i srednjeg poduzetništva. Jednostavno rečeno, Ministarstvo gospodarstva brine o razvoju standardnih inovacija koje nisu zasnovane na razvoju i istraživanju, dok je cilj Ministarstva znanosti potaknuti inovacije koje su zasnovane na znanstvenom znanju. Takve inovacije temelje se na komercijalizaciji istraživanja, suradnji znanosti i gospodarstva i transferu znanja među sektorima, te je Ministarstvo znanosti odgovorno za institucije i programe koji služe ostvarenju navedenog cilja i čine inovacijski sustav u užem smislu. Za sada ne postoji suradnja između ova dva ministarstva i ostalih tijela državne uprave, niti je u funkciji neko posebno tijelo koje bi vodilo brigu o koordinaciji politika radi usklađivanja strategija razvoja. Stoga, u Hrvatskoj ne postoji tzv. sistemska inovacijska politika (Smits i Kuhlmann, 2004.) koja nastoji identificirati i rješavati najslabije točke ukupnog sustava i otkloniti prepreke koje koče sustav u cjelini bez obzira na vrstu djelatnosti, sektor ili političku nadležnost. Od pokretanja programa HITRA 2001. godine, bilo je nekoliko pokušaja prevladavanja fragmentiranosti inovacijskog sustava i usklađivanja rada ministarstava osnivanjem koordinativnih tijela, a najnoviji napori rezultirali su osnivanjem dvaju tijela 2008. godine. Jedno je Vijeće za Nacionalni inovacijski sustav (VNIS) ${ }^{3}$ osnovano kao savjetodavno tijelo Ministarstva znanosti, obrazovanja i športa s ciljem usklađivanja mjera za uspostavu i provedbu nacionalnog inovacijskog sustava. Drugo je vladino strategijsko tijelo nazvano SVEZNATE ${ }^{4}$ kojemu je cilj provedba znanstvene i tehnologijske politike. Na čelu SVEZNATE-a je predsjednik Vlade, a u članstvu predstavnici najvažnijih ministarstva. Sudeći prema dostupnim dokumentima o radu ovih tijela, čini se da niti jedno nije u funkciji.

3 Web stranica: $\underline{\text { http: } / / \text { public.mzos.hr/Default.aspx?art=9227\&sec=2169 }}$

4 Web stranica: http://www.nis.hr/sveznate-i-vnis 
Slika 1.

Hrvatski inovacijski sustav

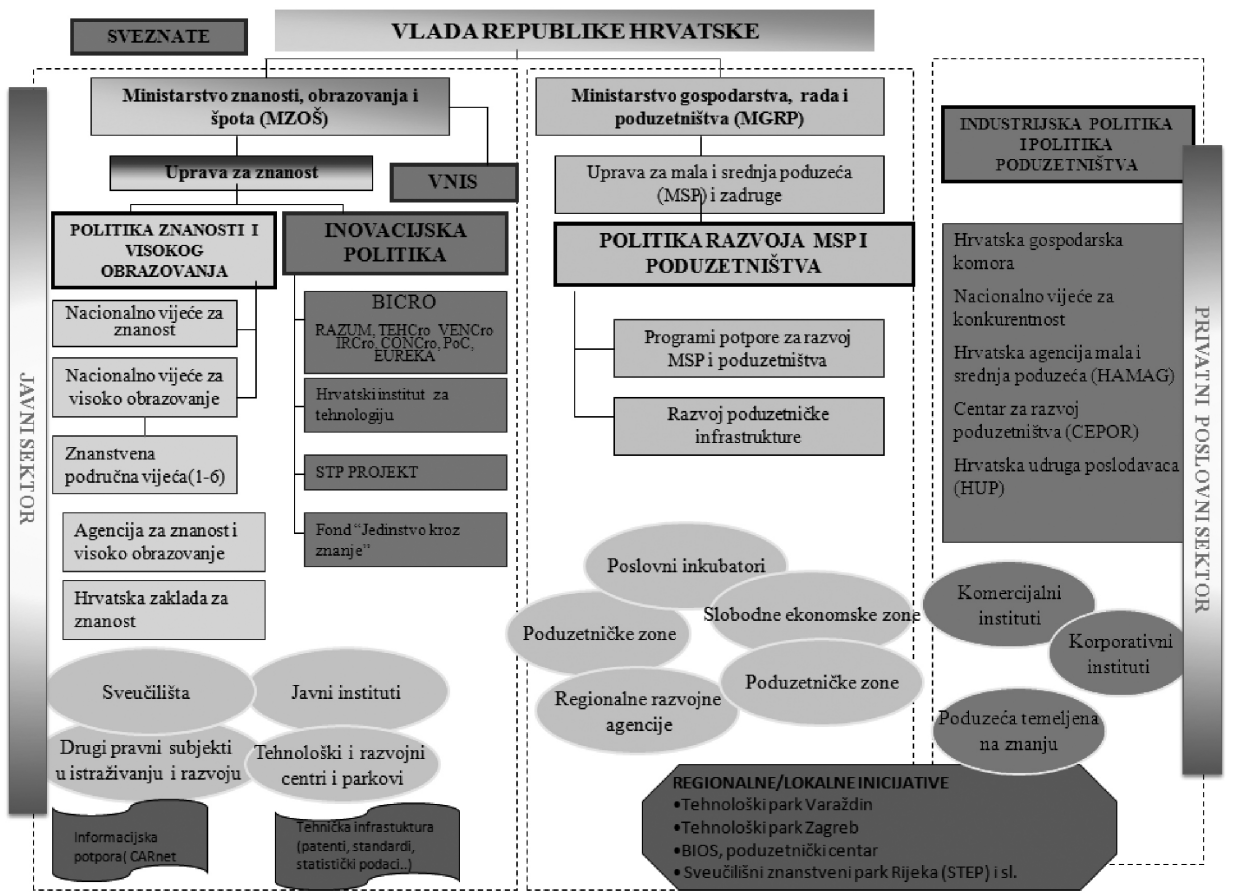

Izvor: prilagođeno iz Švarc, 2009.

Inovacijski sustav u užem smislu čine dvije krovne institucije namijenjenu poticanju inovacija temeljnih na razvoju i istraživanju: Poslovno-inovacijski centar Hrvatske (engl. Business-Innovation Centre of Croatia - BICRO) i Hrvatski institut za tehnologiju (HIT). Potonji je osnovan 2006. godine sa glavnom zadaćom stvaranja podloge za utvrđivanje nacionalne tehnologijske politike i jačanja trokuta znanja ("knowledge triangle" - veze između obrazovanja, istraživanja i inovacija. Također, postoji i mreža tehnoloških centara, tehnoloških parkova, te odnedavno i sveučilišnih ureda za transfer tehnologije. BICRO provodi niz programa kao što su TehCro (razvoj tehnološke infrastrukture), IRCro (stimuliranje potražnje poduzeća za znanstvenim uslugama), KonCro (unapređenje poslovne konkurentnosti kroz konzultantske usluge), VenCro (osnivanje fonda rizičnoga kapitala), te PoC (provjera izvodljivosti ideje). BICRO provodi i Program razvoja na znanju utemeljenih poduzeća (RAZUM program), a koji je zajedno s programom Tehnologijski projekti (TEST) činio okosnicu HITRA programa 2001. godine. TEST program koji je korišten u ovom istraživanju za socijalnu evaluaciju inovacijske politike u Hrvatskoj, danas je u nadležnosti Hrvatskog instituta za tehnologiju koji, također, obavlja i niz drugih djelatnosti ${ }^{5}$ kao

5 Vidjeti web stranicu Instituta: http://www.hit.hr/web/ 
što je pomoć istraživačima za sudjelovanje u Europskim okvirnim programima kroz mrežu nacionalnih kontakt osoba i slično. Također, 2005. godine započelo je financiranje djelatnosti u sklopu Znanstveno-tehnologijskog projekta Ministarstva znanosti, obrazovanja i športa i Svjetske banke kao što su "Ruđer inovacije", restrukturiranje odabranih znanstvenih instituta, sufinanciranje programa BICRO-a, te programa "Jedinstvo kroz znanje" kojemu je cilj suradnja s hrvatskom znanstvenom dijasporom (Švarc, 2011.).

Unatoč, dakle, niza institucija, programa i aktivnosti, inovacijska politika u Hrvatskoj nije prepoznata od strane političke elite kao važna razvojna politika. Razlog ponajprije leži u činjenici da su tehnološki razvoj i inovacije u Hrvatskoj izgubile bitku s gorućim problemima kao što je privatizacija, nelikvidnost, korupcija, brodogradnja, neodržive socijalne beneficije i sl. koje generiraju ekonomsku stagnaciju i nezaposlenost i troše razvojnu energiju.

U suštini, ako pogledamo "iza" formalno-institucionalnog okvira inovacijskog sustava Hrvatske, možemo zaključiti da je inovacijska politika prebačena u nadležnost par vladinih agencija u nadležnosti Ministarstva znanosti, obrazovanja i športa (BICRO i HIT) koje stoje van političkog "mainstream"-a i s vrlo malim utjecajem na razvojnu politiku. Isto tako, inovacijska politika Ministarstva koju možemo okarakterizirati kao science push politiku razvoja, nije usklađena s inovacijskom politikom Ministarstva gospodarstva, rada i poduzetništva koja je, uvjetno rečeno, orijentirana na stvaranje potražnje (market demand) za istraživanjima tj. na razvoj poduzetništva i tehnoloških kompetencija, te nema niti sinergije između ove dvije politike.

Sve to dovodi do relativno male učinkovitosti inovacijske politike i pojedinih programa, što nas dovodi na teren evaluacije inovacijskih sustava i politike u Hrvatskoj.

Program HITRA povrgnut je u zadnje vrijeme raznolikim kritikama ${ }^{6}$ koje odriču ovom programu značaj za tehnološki i gospodarski razvoj, te tvrde da je HITRA u suštini:

- neučinkovita tj. da predstavlja rasipanje javnog novca na projekte koji nisu rezultirali tehnološkim i komercijalnim rezultatima;

- korumpirana, kako od strane administracije koja dijeli sredstva bez objektivnih kriterija, tako i znanstvenika koji privatnim utjecajem dolaze do javnog novca;

- etički upitna jer promovira komodifikaciju znanosti, dok je zadatak javnih instituta i sveučilišta provedba istraživanja od općeg društvenog interesa i pomicanje granica znanstvenih dostignuća.

Činjenica je, međutim, da nadležno Ministarstvo znanosti, obrazovanja i športa kao i vladine agencije koje provode programe (BICRO, HIT) nisu do sada javnosti prikazale neke rezultate evaluacije HITRA programa, barem onih kao TEST i RAZUM

6 Vidi npr. Connect portal 
koje se provode već više od 7 godina, i koje bi dale procjenu uloge i značenja ovih programa u znanstveno-tehnološkoj politici. Za vjerovati je da glavni razlozi ne leže toliko u nedostatku mjerljivih rezultata jer je, primjerice, samo TEST program financirao skoro tristo projekata u 7 godina koji su zasigurno proizveli odrecen broj novih proizvodnih procesa, prototipova, demonstracijskih modela, tehnološka unapređenja. Selektivan prikaz rezultata dao je predsjednik Tehnologijskog vijeća na skupu u Hrvatskoj gospodarskoj komori, ali bez većih odjeka u javnosti (Risović, 2008.).

Pretpostavljamo da su razlozi manjka standardnih evaluacija više socio-kulturnog karaktera i povijesnog naslijeđa (Švarc and Lažnjak, 2008.), te da uključuju najmanje tri elementa:

1. dugoročne i stoga tradicionalne orijentacije javne administracije na klasične metode bibliometrijske i scientometrijske evaluacije isključivo znanstvenika i projekata;

2. općenito pomanjkanje evaluacijske kulture, te znanja i kompetencija javne administracije za evaluaciju znanstvenih /inovacijskih programa;

3. pomanjkanje svjesnosti o ulozi evaluacije za učenje upravljanjem inovacijskim procesima (policy learning) i uloge evaluacije u strateškom razvoju

U nedostatku sumativne evaluacije inovacijskih programa u smislu procjene njihove uspješnosti i učinkovitosti standardnim ekonomskim i statističkim indikatorima (performing indicators), učinjen je pokušaj razvoja i primjene socijalne evaluacije po uzoru na ciljeve formativne evaluacije, a temeljem primjene sociološkog koncepta namjeravanih i nenamjeravanih posljedica (Merton, 1936.) i poimanja inovacijskog sustava kao skupa institucija, organizacija i njihovih međusobnih veza (Edquist, 1977.:49-50).

\section{Cilj istraživanja, metodologija i uzorak}

Cilj istraživanja bio je otkriti prepreke u ostvarenju željenih ciljeva odabranog inovacijskog programa, u ovom slučaju TEST programa, i temeljem tih prepreka zaključiti o sistemskim nedostacima cijelog inovacijskog sustava. TEST program je prvi vladin program usmjeren na razvoj novih tehnologija (proizvoda, procesa, usluge) do faze originalnog rješenja (prototip, pilot fazi) usmjeren na dvije ciljne skupine: poduzetnike i znanstvenike. Iako su ukupni ciljevi definirani široko ${ }^{7}$, smjernice za provedbu programa (MZT, 2002.) naglašavaju očekivanja da će se rezultati programa komercijalizirati putem patenata/licence, strateškog partnerstva

\footnotetext{
7 Prema Javnom pozivu za prijavu projekta iz 2002. stoji da su Tehnologijski projekti (TP) usmjereni na istraživanje, razvoj i usvajanje naprednih tehnologija (procesa/postupaka, proizvoda, usluga), a obuhvaćaju predkomercijalni razvoj proizvoda i tehnologija do faze originalnih rješenja (prototipa/pilot faze).
} 
s tvrtkama, novih spin-offs/start-up poduzeća u sklopu ili izvan programa RAZUM ili će se iskoristiti i na druge načine. Osim toga, TEST programu je dodijeljena pionirska uloga uspostavljanja novog institucionalnog okvira, odnosno postavljanja procedura i pravila za podupiranje suradnje znanosti i industrije koja do sada nisu postojala u znanstvenoj politici, a obuhvaća, primjerice: potporu poduzećima za suradnju s industrijom, ugovor o pravima intelektualnog vlasništva, osnivanje Tehnologijskog vijeća, uvođenje javne obrane projekata, provjere odvijanja projekta na terenu i sl.

O preprekama u provedbi TEST programa zaključilo se indirektno - analizom namjeravanih, nenamjeravanih i neostvarenih posljedica programa. Polazna je teza da implementacija TEST programa, kao i mnoge druge akcije ili intervencije u društvu, dovode osim do namjeravanih (intended) isto tako i do niza nenamjeravanih (unintended) i neostvarenih (failed) posljedica. Ove potonje premještaju fokus TEST programa s komercijalizacije istraživanja i suradnje znanstvenog i gospodarskog sektora kao očekivanih posljedica - ka neočekivanim posljedicama koje se očituju u postizanju znanstvenih rezultata kao finalizaciji TEST projekta, a koji služe uglavnom potrebama znanstvenika za nastavak znanstvenih projekata.

Provedena socijalna evaluacija temelji se na dva teorijska izvora. Prvi je teorija nenamjeravanih posljedica Roberta Mertona (Merton, 1936.) temeljem koje smo pretpostavili da je TEST program proizveo pored očekivanih efekata i niz nenamjeravanih posljedica, od kojih neke mogu biti i disfunkcionalne za uspješnost programa.

Druga je teorija institucionalnih deficita koje je razvio Edquist (1997.:49-50) oslanjajući se na institucionalnu teoriju D. Northa (North, 2003.). Prema Edquistu, osnovne komponente inovacijskog sustava su: organizacije, institucije i veze među njima, pri čemu treba, također, razlikovati formalne institucije koja obuhvaćaju formalna pravila (zakoni, direktive, pravilnici) i neformalne institucije koje obuhvaćaju pravila ponašanja, dakle norme, običaje, kolektivne, navike, vrijednosti i sl., dakle institucije u sociološkom smislu. Ove organizacije i institucije značajno se razlikuju s obzirom na nacionalne inovacijske sustave uzrokujući razlike u njihovoj učinkovitosti i uspjehu. Slično teoriji tržišnih nedostataka koja teži da ukloni nedostatke tržišta u stvaranju inovacija, institucionalni pristup teži otkriti institucionalne propuste povezane $s$ formalnim institucijama (pravila i propise) i neformalnim institucijama (društveno-političkom kontekstu, vrijednosne orijentacije, norme ), kao i propuste vezane uz njihove interakcije s organizacijama.

Ako teoriju D. Edquista ekstrapoliramo na analizu TEST-a, onda bi ključne organizacije bile Ministarstvo znanosti, obrazovanja i sporta,Tehnologijsko vijeće, znanstveni instituti i sveučilišta, te privatna i javna poduzeća. Ključna formalna institucija je program HITRA s pripadajućim pravilima i procedurama kao što su kriteriji za odabir ili prijavu projekta, način financiranja i praćenja projekata i sl. Najkompleksnije su neformalne institucije koje obuhvaćaju socio-kulturne značajke glavnih sudionika u programu, njihove vrijednosne orijentacije, norme i kognitivne 
mape koje je najteže definirati i mjeriti, a koje vrše snažan utjecaj na način funkcioniranja organizacija i institucija i njihovu interakciju.

Koncept institucionalnog deficita u ovom istraživanju čine tri tipa institucionalnog deficita: /1/ administrativni deficit (službena pravila i procedure programa; /2/ nedostatak socijalnog kapitala (neformalne institucije); /3/ nedostaci šireg socioekonomskog okruženja (manjak interesa poduzeća za inovacije i suradnju sa znanstvenim sektorom).

Namjeravane, nenamjeravane i neostvarene posljedice smo analizirali unutar sedam dimenzija TEST programa, i to: /1/ motivacija za sudjelovanje u programu, /2/ izvori financiranja projekata, /3/ realizacija (postignuti rezultati i "follow-up" aktivnosti), /4/ izvodljivost (razlozi neuspjeha komercijalizacije) /5/ kvaliteta provedbe programa (financijska kontrola i nadzor) /6/ utjecaj programa TEST na ulogu znanosti u društvu, /7/ utjecaj programa TEST na znanstvenu politiku. Ovih sedam dimenzija čini osnovne zavisne varijable u našem istraživanju.

Institucionalni deficit operacionaliziran je preko slijedećih nezavisnih varijabli:

1. Socijalni kapital mjeren kao vrijednosne orijentacije (tradicionalizam, antiglobalizam i etatizam) i povjerenje u institucije (znanosti, obrazovanja, policije, vojske, vlade, političke stranke);

2. Stavovi prema komercijalnoj primjeni znanosti, te suradnji znanosti i industrije;

3. Stavovi prema tradicionalnom i poduzetničkom tipu sveučilišta;

4. Stavovi prema gospodarskom okruženju (strateško partnerstvo i suradnja s poduzećima) i potrebnoj infrastrukturi.

Istraživanje administrativnog deficita temeljilo se na analizi službene dokumentacije (javni poziv, smjernice, formulari za prijavu) vezane uz provedbu programa TEST (MZT, 2002.) u cilju razumijevanja utjecaja formalnih pravila i procedura na uspješnost programa.

Također, upitnik je mjerio i mogući utjecaj osnovnih socio-demografskih varijabli kao što su rod, dob, tip institucije zaposlenja, područje istraživanja, publikacije.

Svi indikatori mjereni su temeljem percepcije ispitanika. Svi stavovi mjereni su standardnom Likertovom skalom (1 - uopće se ne slažem; 2 - ne slažem se; 3 - ne mogu odlučiti; 4 - slažem se; 5 - u potpunosti se slažem).

Upitnik se sastojao od 53 pitanja grupirana u 6 tematskih područja koja su omogućila mjerenje odabranih sedam dimenzija TEST programa.

Podaci su prikupljani u jesen 2007. godine klasičnim poštanskim upitnikom poslanim voditeljima 212 tehnologijskih projekta (TEST projekti) koji su se vodili kao završeni TEST projekti na web stranicama MZOS-a u sklopu HITRA programa na 
dan 27. 02. 2007. Dakle, radi se prigodnom uzorku budući da nismo imali uvid u cjelokupnu populaciju sudionika TEST programa. Ukupno je prikupljeno i obrađeno 120 anketa što čini 57\% odziva. Zbog toga, nismo dobili uvid u stavove voditelja nezavršenih projekata i neuspješnih prijedloga projekata što bi učinilo evaluaciju relevantnim, te se predviđa budućim istraživanjem.

Većina ispitanika u uzorku je sa sveučilišta (76\%), a samo 17\% su iz javnih instituta. Oko 65\% ispitanika su muškarci, a 35\% su žene. Velika većina njih (93,3\%) ima doktorat znanosti. Većina ih dolazi iz tehničkih znanosti (45\%), biotehničkih znanosti i biomedicine (28\%), a samo $14 \%$ su iz područja s prirodnih znanosti, odnosno $10 \%$ iz agronomije i veterinarstva. Neki od ispitanika $(7,5 \%)$ posjeduju vlastite tvrtke, a neki od njih $(9,2 \%)$ rade paralelno u drugim tvrtkama ili ustanovama. Uzorak pokazuje da su neki hrvatski znanstvenici prilično bliski poduzetništvu.

\section{Diskusija rezultata}

Jedan od aspekata društvene evaluacije TEST programa odnosi se na analizu njegove provedbe na temelju tri vrste posljedica koje je proizveo: namjeravanih posljedica, nenamjeravanih posljedica i neostvarenih posljedica. Nakon prikaza navedenih posljedica navodimo samo dio rezultata istraživanja koji se odnosi na institucionalne deficite kao osnovne prepreke ostvarenju inovacijskog programa.

Temeljem službene dokumentacije Ministarstva znanosti, obrazovanja i športa vezane uz provedbu TEST programa (MZT, 2002.) i odgovora ispitanika (Slika 2) zaključeno je da je TEST ostvario važnu namjeravanu posljedicu koja se sastoji u stvaranju formalno institucionalne baze za hrvatsku inovacijsku politiku, time što je uveo niz organizacijskih i formalno-institucionalnih novina u standardnu znanstvenu politiku. Te novine uključuju: formiranje Tehnologijskog vijeća (uz dosadašnja disciplinski orijentirana znanstvena vijeća), nov način prijave, praćenja i evaluacije projekata, orijentaciju istraživanja k primjeni, suradnju znanosti i industrije uz promidžbu gospodarske uloge znanosti i sl. Analiza stavova ispitanika prema TEST programu potvrdila je ostvarenje te namjeravane posljedice (Slika 2).

Glavna nenamjeravana posljedica TEST-a sastoji se u činjenici da su rezultati TEST-a pretežito korišteni, nakon završetka projekta, u znanstvene svrhe ili su završili "u ladici". Oko 15\% projekata je komercijalizirano, a rezultati na oko 40\% projekata su iskorišteni kao podloga za daljnju suradnju s industrijom (Slika 3) što se može ubrojiti u nenamjeravane posljedice TEST-a. Iako 15\% komercijalnih rezultata nije zanemarivo s obzirom na sustavne prepreke u komercijalizaciji istraživanja, može se tvrditi da je većina projekata uhvaćena u "retrogradni krug" koji kreće od znanstvene ideje i nakon pokušaja tehnološke primjene ili komercijalizacije, vraća se svojim polazištima, tj. rezultati se ponovo koriste za znanstvena istraživanja. Na taj su način sredstva uložena u TEST program poslužila uglavnom za proširenje znanstvene baze koja ionako pati od pod-financiranosti, ali svakako nisu poslužila u dovoljnoj mjeri za ostvarenje ciljeva programa. 
Slika 2.

Stavovi prema TEST programu kao novom instrumentu inovacijske politike

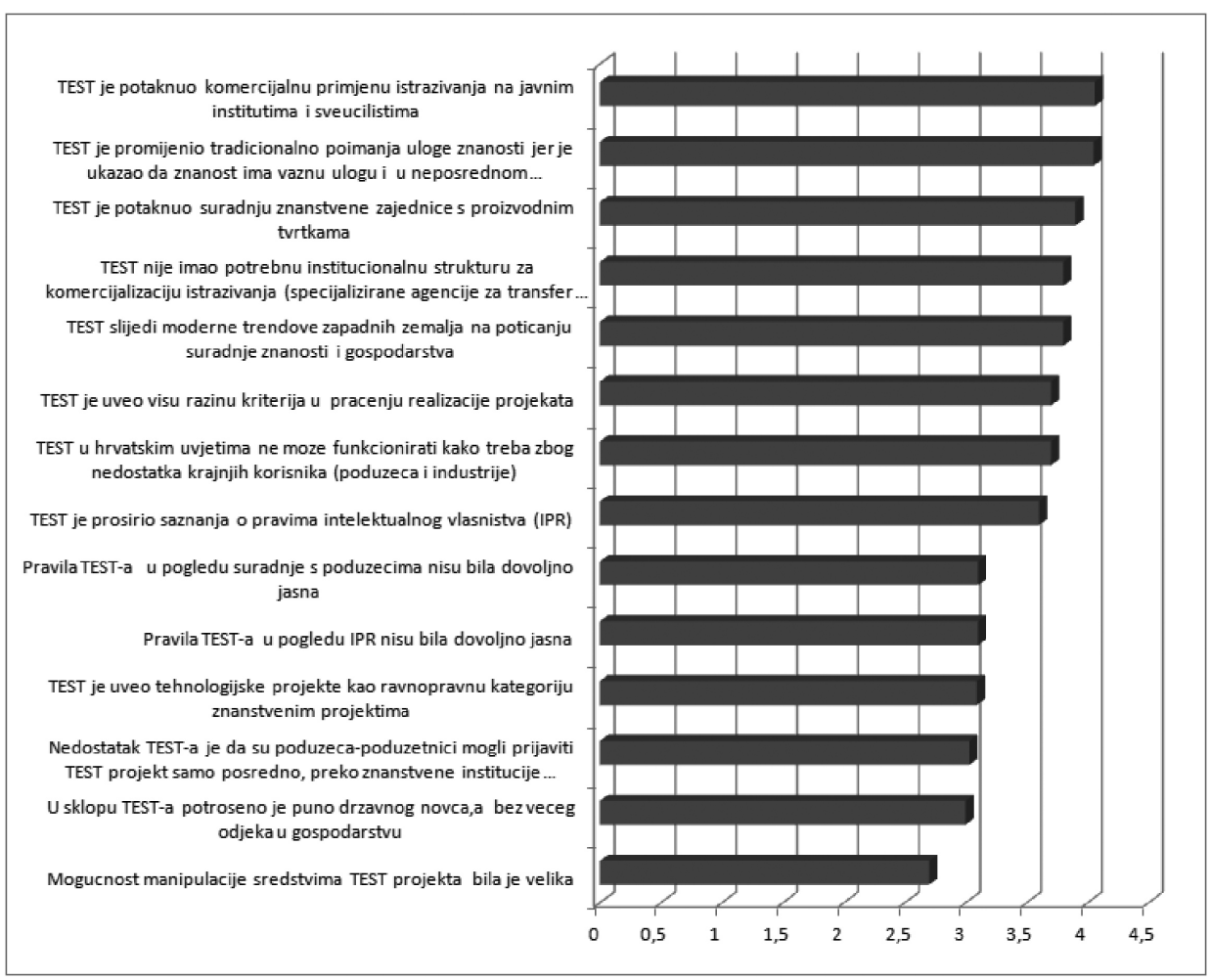

1 - uopće se ne slažem; 2 - ne slažem se; 3 - ne mogu odlučiti; 4 - slažem se ; 5 - u potpunosti se slažem

U skladu s nenamjeravanom posljedicom TEST-a (korištenje rezultata u druge svrhe od komercijalizacije), glavna neostvarena posljedica TEST-a odnosi se na činjenicu da većina projekata, njih približno 75\%, nije uspjela komercijalizirati rezultate istraživanja (Slika 3). Pri tom valja naglasiti da do komercijalizacije nije došlo usprkos tome što su sudionici zadovoljili sve formalno-administrativne propozicije natječaja, te su isto tako:

- predložili razvoj nove tehnologije do faze prototipa/pred-komercijalne faze, dakle projekte koji su imali komercijalni potencijal;

- postigli formalno-predviđene rezultate programa definirane završnim izvješćem projekta, a koji su predviđali tri moguće vrste rezultata: završna izvješća, prijavu projekta na program RAZUM ili studiju ostvarljivosti; od ukupnog broja projekata, $72 \%$ je proizvelo završna izvješća (opis rada i postignuća), 7\% je prijavilo projekt na RAZUM program, a $19 \%$ je izradilo studiju ostvarljivosti; 
Slika 3.

Što se dogodilo nakon završetka projekta (moguće više odgovora)

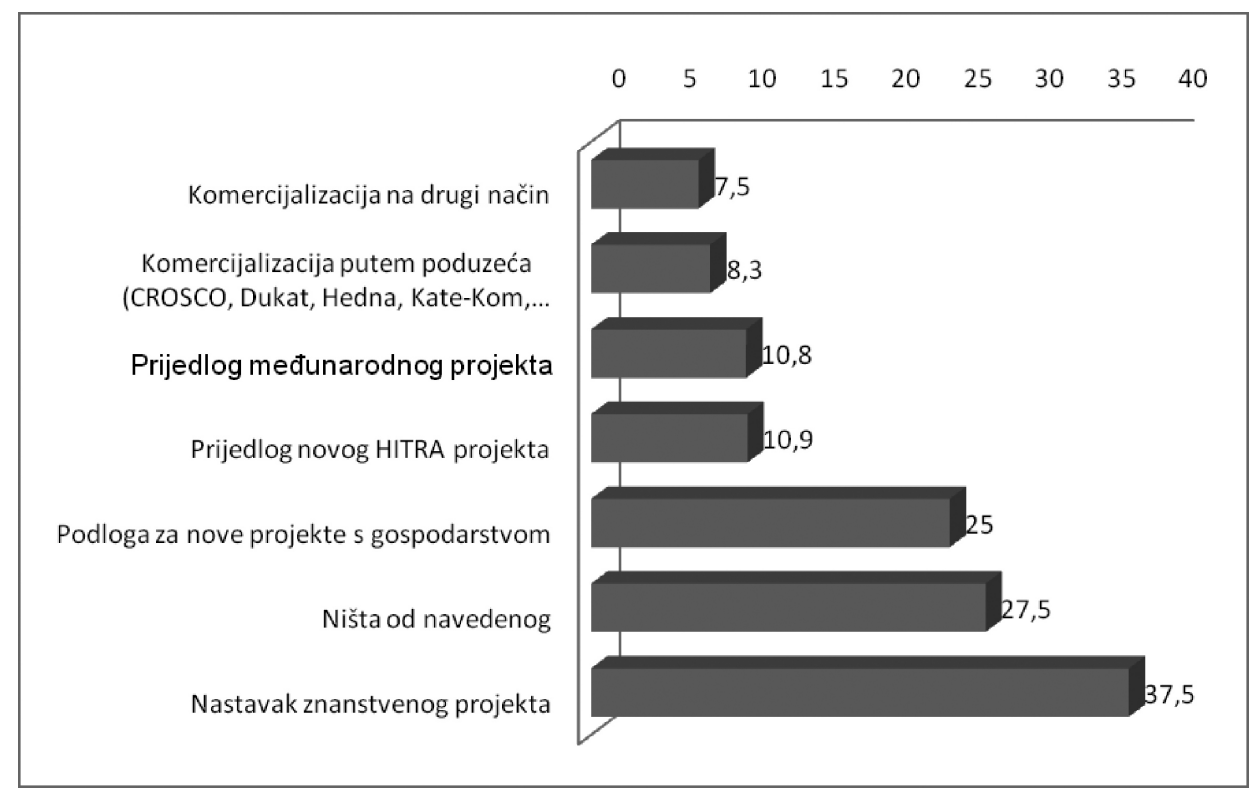

Isto tako, prilikom provedbe programa vodilo se račina o kvaliteti procesa koje je uključivala:

- detaljnu evaluaciju prijedloga projekata od strane dva neovisna recenzenta, procjenu Tehnologijskog vijeća i javna obranu projekta što je ostavljalo relativno mali prostor za manipulaciju);

- kontrolu provedbe projekta koja je prema procjenama sudionika bila primjerena (tako smatra 70\% ispitanika) ili pretjerana (10\% ispitanika), odnosno prosječna (20\% ispitanika).

Ova analiza pokazuje da udovoljavanje propozicijama natječaja i njegovo "uredno" provođenje nije dovoljno za postizanje ciljeva nekog programa ili politike, već da postoji niz ostalih institucionalnih deficita, među kojima je administrativni deficit - (ne)sposobnost formuliranje pravila i procedura programa tako da se postignu ciljevi, od ključnog značaja (vidjeti slijedeće poglavlje).

Neke od ostalih neostvarenih i nenamjeravanih posljedica TEST-a jesu sljedeće:

- Program je mobilizirao uglavnom znanstvenu zajednicu tj. projektne ideje dolaze većim dijelom od znanstvenika i vezane su uz područje rada znanstvenih projekata (72\%), dok svega $20 \%$ ideja dolazi iz industrije ili poduzeća ili je vođeno isključivo primjenom. 
- Izvor sredstava većinom je bilo Ministarstvo znanosti, obrazovanja i športa (50\% projekata koristilo je isključivo sredstva MZOS-a). Vidljiva je slaba zastupljenost poduzeća u financiranju projekata što je podatak koji ponajbolje ilustrira mali interes gospodarstva za istraživačke projekte i slabu interakciju istraživača i poduzetnika. Tako, $62 \%$ projekta nisu dobili uopće bilo kakvo su-financiranje od poduzeća, 27\% projekata je financirano sa sredstvima do simboličnih do 30\% u ukupnom budžetu projekta, a 12\% projekta je dobilo sredstva od poduzeća iznad 30\% ukupnom budžetu projekta;

- Publicirani rezultati su uglavnom znanstveni jer uključuju 417 radova (znanstveni 66\%, stručni 28\%, knjige 6\%) dok je prijavljenih patenata bilo 21;

- Komercijalizacija rezultata projekta predlagateljima nije bila u prvom planu, na što nedvosmisleno ukazuju podaci da samo 17\% ispitanika ima konkretan plan komercijalizacije dok čak 82\% ima nejasnu ideju o komercijalizaciji; odnosno 40\% ispitanika uopće nije odgovorilo na pitanje o planu komercijalizacije (Slika 4);

- Motivi sudjelovanja znanstvenika u TEST projektima su prvenstveno iskustvene i znanstvene naravi jer 65\% ispitanika želi dobiti dodatno iskustvo u suradnji s industrijom, 64\% ispitanika očekuje od projekta kupiti opremu koja uglavnom služi za znanstveno-nastavni rad, a 50\% želi dobiti dodatna sredstva za znanstveni projekt; drugim riječima istraživači kombiniraju svoje znanstvene motive i motive za suradnju s industrijom, pri čemu je primjena dobro-došao rezultat, ali ne i primarni motiv sudjelovanja na TEST programu (Slika 5).

Slika 4.

Plan komercijalizacije

Proširivanje ugovornih istraživanja s gospodarstvom Testiranje, provjera kvalitete i slične usluge

Pokretanje proizvodnje unutar poduzeća gdje radim

Pokretanje proizvodnje u strateškom partnerstvu

Prodaja licence - patentnih prava

Zasnivanje vlastitog poduzeća

Nešto drugo

bez odgovora
21,7

16,7

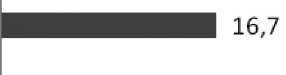

11,7 
Slika 5.

Motivi za sudjelovanje u TEST programu

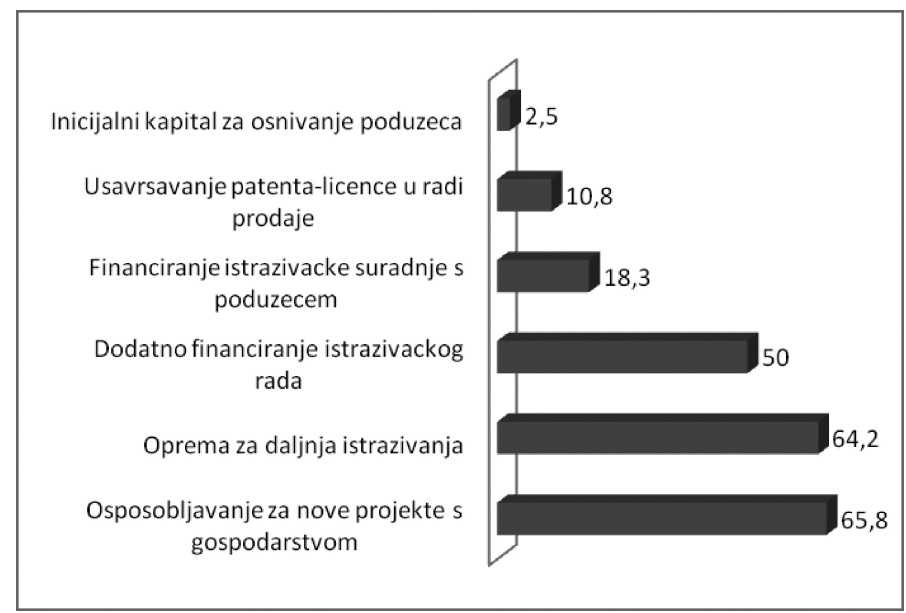

Ova analiza ukazuje da udovoljavanje propozicijama natječaja i njegovo "uredno" provođenje nije dovoljno samo po sebi za postizanje ciljeva programa/politike, već da postoji niz institucionalnih deficita koji priječe uspješnost programa, a koji su objašnjeni u slijedećem poglavlju.

\section{Institucionalni deficiti}

Glavni pokretači ovih neostvarenih i nenamjeravanih posljedica identificirani su, oslanjajući se na institucionalističku teoriju Edquista (1997.), u tri institucionalna deficita: /1/ administrativnom deficitu ili službenim pravilima i procedurama programa koje su usko povezani s upravljanjem HIS-om (formalne institucije); /2/ nedostatku socijalnog kapitala (neformalne institucije); /3/ nedostacima šireg socio-ekonomskog okruženja, prvenstveno u nedostatku interesa poduzeća za inovacije i suradnju sa znanstvenim sektorom, te u /4/ pomanjkanju intermedijarne tehnološke infrastrukture kao što su centri za tehnološki transfer i slično.

U pogledu administrativnog deficita - službenih pravila i procedura, najveći je nedostatak bio u tome što su pravila TEST programa u velikoj mjeri ograničavala sudjelovanje poduzeća/poduzetnika kao samostalnih predlagatelja projekata. Oni su projekt mogli provoditi samo preko znanstvene ustanove što ih je dovodilo u neravnopravan položaj, te je navelo mnoge poduzetnike da odustanu od projekta. Ovo je pravilo uglavnom rezultat fragmentacije inovacijske politike i pomanjkanja koordinacije i suradnje između dva ključna ministarstva - Ministarstva znanosti, obrazovanja i športa i Ministarstva gos- 
podarstva, rada i poduzetništva. Ova dva ministarstva potenciraju, umjesto harmonizacije razvojne politike, želju za razgraničenjem ovlasti na taj način da MZOS koordinira samo one programe koje imaju temelj u znanstveni aktivnostima, dok poduzetnici pripadaju sferi utjecaja MINGORP-a. Rezultat je bio, kao što je analiza pokazala, zanemarivo sudjelovanje gospodarstvenika u programu i postizanje pretežito znanstvenih, a ne tehnoloških rezultata s ekonomskim učincima.

Osim toga, administracija nije osmislila mjere za nastavak TEST-a osim RAZUM programa što otvara niz nedoumica o svrsishodnosti, poželjnosti i mogućnostima transformacije znanstvenika u poduzetnika. Pojedinci koji se opredijelili za karijeru znanstvenika rijetko imaju karakteristike dobrog poduzetnika, osim u rijetkim slučajevima, što treba respektirati i podržavati.

Konačno, uloga vlade u HIS-u je minorna jer nije jasno odredila nove tehnologije i znanje kao strateške resurse razvoja već se razvoj uglavnom temelji na ideji kombinacije poljoprivrede i turizma što mnogi cinično nazivaju "zemljom seljaka i konobara". Politička trgovina dovela je forsiranja obiteljskih gospodarstva umjesto razvoja novih tehnologija što je hrvatsku poljoprivredu i poljoprivrednike dovelo, kako se sada pokazuje, do ruba propasti. Politička trgovina i korupcija kriva je što politička elita nije preuzela odgovornost za objedinjavanje grupnih interesa i stvaranja zajedničke platforme razvoja primjerene 21. stoljeću i razvojnim potencijalima Hrvatske.

U pogledu šireg gospodarskog konteksta, najveći je nedostatak u nepostojanju interesa gospodarstva za stvaranje inovacija i suradnju sa znanstvenim institucijama. Ispitanici procjenjuju da je najveća prepreka komercijalizaciji rezultata istraživanja u nedostatku strateškog partnera i nezainteresiranosti gospodarstva. Pored toga, visoko na ljestvici prepreka kotira i nedostatak podrške u okruženju, odnosno institucija za potporu tehnološkom transferu i komercijalnoj primjeni rezultata istraživanja (Tablica 1).

Osim toga, analiza stavova ispitanika prema TEST programu pokazala je da TEST ne može dobro funkcionirati upravo zbog navedena dva razloga: jer nema krajnjih korisnika - poduzeća i industrije s čim se slaže se $67 \%$ ispitanika i jer nema potrebnu infrastrukturu za tehnološki transfer s čim se slaže 65\% ispitanika.

Konačno, nedostatak socijalnog kapitala kao što su prethodne analize pokazale (Švarc, Lažnjak, Šporer 2009.) predstavlja ozbiljnu prepreku u funkcioniranju inovacijskog sustava. Standardni indikatori socijalnog kapitala kao norme,vrijednosti i povjerenje u institucije operacionalizirani su kroz 4 indikatora: /1/ stavovima prema tradicionalnom i poduzetničkom sveučilištu; /2/ stavovima prema komercijalizaciji znanosti; /3/ općim vrijednosnim orijentacijama i /4/ povjerenjem u institucije. 
U tu svrhu konstruirane su dvije odvojene skale stavova. Prva skala "Stavovi prema komercijalizaciji znanosti" mjeri razlike u stavovima prema komercijalizaciji istraživanja i kooperaciji znanosti i industrije, dok se druga skala "Tradicionalno i poduzetničko sveučilište" odnosi na ulogu sveučilišta s naglaskom na novi tip odnosa između sveučilišta, industrije i države. Također je konstruirana skala općih vrijednosnih orijentacija. Skale su dobivene faktorskom analizom, metodom principijelnih komponenti i varimax rotacijom. Koeficijent konzistentnosti skala je prikazan u tablicama ${ }^{8}$.

Tablica 1.

Prepreke komercijalizaciji

\begin{tabular}{|l|c|c|c|}
\hline & N & $\begin{array}{c}\text { Aritmetička } \\
\text { sredina }\end{array}$ & $\begin{array}{c}\text { Standardna } \\
\text { devijacija }\end{array}$ \\
\hline Nemogućnost pronalaska strateškog partnera za komercijalizaciju & 65 & 3,57 & 1,531 \\
\hline Nedostatak podrške u okruženju & 65 & 3,43 & 1,287 \\
\hline Nedostatak poslovnih prilika-nezainteresiranost gospodarstva & 66 & 3,42 & 1,458 \\
\hline Nedostatna financijska sredstva & 66 & 3,09 & 1,356 \\
\hline Okupiranost drugim poslovima & 69 & 2,86 & 1,427 \\
\hline Nemogućnost pronalaženja tržišta & 61 & 2,85 & 1,515 \\
\hline Nedostatak "menadžerskih" sposobnosti tima & 64 & 2,80 & 1,287 \\
\hline Neusklađenost pravne regulative različitih ministarstava & 57 & 2,61 & 1,567 \\
\hline Nedostatna upornost na tržišnoj realizaciji ideje (inertnost tima) & 62 & 2,56 & 1,276 \\
\hline Nedovoljna tržišna isplativost ideje (rezultata projekta) & 59 & 2,47 & 1,501 \\
\hline Poteškoće u dogovorima oko prava intelektualnog vlasništva & 61 & 1,84 & 1,083 \\
\hline
\end{tabular}

*1 - uopće se ne slažem; 2 - ne slažem se; 3 - ne mogu se odlučiti; 4 - Slažem se; 5 - u potpunosti se slažem

8 Statistički podaci dostupni na upit. 
Tablica 2.

Stavovi prema komercijalizaciji znanosti

\begin{tabular}{|c|c|}
\hline Industrija nije zainteresirana za kooperaciju sa znanošču & $\begin{array}{c}\text { Cronbach's } \\
\text { Alpha }\end{array}$ \\
\hline $\begin{array}{l}\text { Veliki gospodarski subjekti ne prepoznaju upotrebljivost naših znanstvenih istraživanja } \\
\text { Postoji premali broj poduzetnika/poduzeća koji su zainteresirani za suradnju s znanstvenim } \\
\text { institucijama } \\
\text { Strani vlasnici poduzeća nisu zainteresirani za upotrebu hrvatske znanosti već razvojne } \\
\text { djelatnosti zadržavaju u matičnim državama }\end{array}$ & .724 \\
\hline \multicolumn{2}{|l|}{ Elitna znanost } \\
\hline $\begin{array}{l}\text { Znanstvenici i sveučilišni nastavnici ne žele se baviti komercijalnom primjenom znanosti } \\
\text { i surađivati s gospodarstvom jer rezultati takvih djelatnosti ne pridonose znanstvenom } \\
\text { napredovanju } \\
\text { U hrvatskoj akademskoj zajednici prevladava kultura elitne znanosti i "Current Contents-a" i } \\
\text { "Web of Science" } \\
\text { Država nije pokrenula velike razvojne programe koji bi uključivali i suradnju znanosti i } \\
\text { gospodarstva (npr. tehnologijske platforme, istraživačke konzorcije) }\end{array}$ & .544 \\
\hline \multicolumn{2}{|l|}{ Inertna i loša znanost } \\
\hline $\begin{array}{l}\text { Znanstvenici i sveučilišni nastavnici često su inertni i nemaju dovoljno poticaja za komercijalne } \\
\text { projekte i suradnju s gospodarstvom } \\
\text { Gospodarstvo nije zadovoljno načinom rada hrvatskih znanstvenih instituta i sveučilišta } \\
\text { U Hrvatskoj nema mobilnosti istraživačkog kadra između znanstvenog i gospodarskog sektora } \\
\text { što onemogućava protok znanja } \\
\text { U našoj znanstvenoj zajednici prevladava svjetonazor da nije etično prodavati znanstvene } \\
\text { rezultate i raditi "business" od znanosti kao javne djelatnosti }\end{array}$ & .584 \\
\hline \multicolumn{2}{|l|}{ Deficit tehnološkog transfera (infrastrukture) } \\
\hline $\begin{array}{l}\text { Pri znanstvenim institutima i sveučilištima nedostaju agencije/uredi koje bi aktivno podržavale } \\
\text { komercijalnu primjenu istraživanja (zaštita patenata, traženje korisnika i sl.) } \\
\text { Postojeća tehnologijska infrastruktura u Hrvatskoj (tehnologijski centri, poslovno-inovacijski } \\
\text { centri) nije funkcionalna }\end{array}$ & .625 \\
\hline
\end{tabular}

Tablica 3.

Srednje vrijednosti za skalu stavova prema komercijalizaciji znanosti

\begin{tabular}{|l|c|}
\hline Stavovi prema komercijalizaciji znanosti & $\begin{array}{c}\text { Arit. } \\
\text { sredina }\end{array}$ \\
\hline Industrija nije zainteresirana za kooperaciju sa znanošću & 3.8739 \\
\hline Elitna znanost & 3.7871 \\
\hline Inertna i loša znanost & 3.4804 \\
\hline Deficit tehnološkog transfera (infrastrukture) & 4.1134 \\
\hline
\end{tabular}


Tablica 4.

Poduzetničko i tradicionalno sveučilište

\begin{tabular}{|c|c|c|c|}
\hline Poduzetničko sveučilište & $\begin{array}{l}\text { Arit. } \\
\text { sredina }\end{array}$ & $\begin{array}{l}\text { Std. } \\
\text { devijacija }\end{array}$ & $\begin{array}{l}\text { Cronbach's } \\
\text { Alpha }\end{array}$ \\
\hline $\begin{array}{l}\text { Osnovni je zadatak javnih znanstvenih instituta-visokih učilišta } \\
\text { da pored temeljnih istraživanja provode i razvojna i primijenjena } \\
\text { istraživanja }\end{array}$ & 4,49 & ,601 & \multirow{10}{*}{, 595} \\
\hline $\begin{array}{l}\text { Osnovni je zadatak javnih znanstvenih instituta-visokih učilišta da } \\
\text { provode istraživanja koja su namijenjena neposrednoj praktičnoj } \\
\text { primjeni }\end{array}$ & 3,33 & 1,344 & \\
\hline $\begin{array}{l}\text { Javni znanstveni instituti i visoka učilišta morala bi biti djelomično } \\
\text { financirani od poduzeća }\end{array}$ & 3,73 & 1,018 & \\
\hline $\begin{array}{l}\text { Ideja Lisabonske agende da } 2 / 3 \text { sredstava za znanstvena istraživanja } \\
\text { treba osigurati gospodarstvo je dobra i treba je nastojati provesti i u } \\
\text { Hrvatskoj }\end{array}$ & 3,36 & 1,219 & \\
\hline $\begin{array}{l}\text { Ideja Lisabonske agende da } 2 / 3 \text { sredstava za znanstvena istraživanja } \\
\text { treba osigurati gospodarstvo je dobra, ali nerealna za uvjete u Hrvatskoj }\end{array}$ & 3,70 & 1,262 & \\
\hline $\begin{array}{l}\text { Svi znanstveni instituti i visoka učilišta moraju voditi brigu oko } \\
\text { komercijalizacije (patentiranja-licenciranja) rezultata istraživanja }\end{array}$ & 3,76 & 1,138 & \\
\hline $\begin{array}{l}\text { Akademsko poduzetništvo je korisno jer omogućava znanstveniku da } \\
\text { bude i poduzetnik i tako komercijalizira svoje znanje }\end{array}$ & 3,47 & 1,052 & \\
\hline $\begin{array}{l}\text { Suradnja znanstvenih institucija i visokih učilišta s gospodarstvom je } \\
\text { poželjna kao izvor novih ideja i znanja }\end{array}$ & 4,50 &, 570 & \\
\hline $\begin{array}{l}\text { Suradnja znanstvenih institucija i visokih učilišta s poduzećima- } \\
\text { gospodarstvom je poželjna kao izvor dodatnih materijalnih sredstava }\end{array}$ & 4,33 &, 778 & \\
\hline $\begin{array}{l}\text { Ideja oko zaštite intelektualnih prava nad rezultatima istraživanja je } \\
\text { dobra jer omogućava znanstvenicima da profitiraju od svog znanja }\end{array}$ & 3,89 & 1,073 & \\
\hline $\begin{array}{l}\text { Osnovni je zadatak javnih znanstvenih instituta-visokih učilišta da } \\
\text { provode temeljna istraživanja koja uvećavaju opću količinu znanja }\end{array}$ & 3,42 & 1,332 & \multirow{10}{*}{, 733} \\
\hline $\begin{array}{l}\text { Javni znanstveni instituti i visoka učilišta moraju biti isključivo } \\
\text { financirani iz javnih sredstava }\end{array}$ & 3,00 & 1,307 & \\
\hline $\begin{array}{l}\text { Financiranje javnih znanstvenih instituta i visokih učilišta od strane } \\
\text { poduzeća štetno je jer slabi znanstvenu objektivnost ("friziranje" } \\
\text { rezultata istraživanja) }\end{array}$ & 2,18 & 1,097 & \\
\hline $\begin{array}{l}\text { Gospodarstvo ne bi trebalo financirati znanost na visokim učilištima i } \\
\text { javnim institutima jer ograničava znanstvenu slobodu i autonomiju }\end{array}$ & 2,27 & 1,160 & \\
\hline $\begin{array}{l}\text { Komercijalizacija istraživanja ne spada u djelokrug rada znanstvenih } \\
\text { instituta i visokih učilišta }\end{array}$ & 2,51 & 1,205 & \\
\hline Znanstvenik ne može biti i poduzetnik osim izuzetno & 3,25 & 1,232 & \\
\hline $\begin{array}{l}\text { Akademsko poduzetništvo je loše kao ideja jer netko korištenjem javnih } \\
\text { resursa osniva poduzeće za vlastiti profit }\end{array}$ & 2,88 & 1,256 & \\
\hline $\begin{array}{l}\text { Znanstvene i sveučilišne institucije nemaju što "petljati" s } \\
\text { gospodarstvom već za to trebaju postojati druge institucije (kao centri } \\
\text { za IPR i sl.). }\end{array}$ & 1,76 & ,946 & \\
\hline $\begin{array}{l}\text { Cijela ta ideja oko komercijalizacije znanosti je, u biti, kriva jer znanost } \\
\text { nije poduzetnička djelatnost }\end{array}$ & 2,11 & 1,163 & \\
\hline $\begin{array}{l}\text { Ideja oko zaštite intelektualnih prava nad rezultatima istraživanja je } \\
\text { kriva jer sprečava slobodan protok znanja }\end{array}$ & 2,21 & 1,161 & \\
\hline
\end{tabular}


Tablica 5.

Aritmetička sredina za skalu tradicionalno i poduzetničko sveučilište

\begin{tabular}{|l|c|}
\hline & Arit. sredina \\
\hline Tradicionalno sveučilište & 2,5766 \\
\hline Poduzetničko sveučilište & 3,8623 \\
\hline
\end{tabular}

Analiza je pokazala da ispitanici - glavni istraživači tehnoloških projekata - jesu nositelji socio-kulturnih promjena u standardnoj znanstvenoj politici jer podržavaju komercijalnu primjenu znanosti, suradnju znanosti i industrije, te preferiraju poduzetničko sveučilište u odnosu na tradicionalno sveučilište. Međutim, usprkos tome, oni i nadalje dijele prilično tradicionalni vrijednosni sustav (Tablica 6) s izraženom orijentacijom $\mathrm{k}$ antiglobalizmu i državnom paternalizmu (etatizmu). Na prvi pogled, sklonost ka komercijalnoj primjeni znanosti, s jedne strane, i antiglobalizmu tj. etatizmu, s druge strane, jesu u snažnoj kontradikciji. Antiglobalizam i etatizam priječe, naime, slobodno funkcioniranje tržišta u nacionalnim i međunarodnim okvirima i na taj način sužavaju mogućnosti slobodnog transfera znanosti u nove tehnologije i komercijalne proizvode. Međutim, ove vrijednosne orijentacije najvjerojatnije su uvjetovane upravo pomanjkanjem tržišta za znanstvena istraživanja u Hrvatskoj, odnosno pomanjkanjem interesa poduzeća za inovacije i ujedno za suradnju sa znanstvenim sektorom. Stoga je jedini način preživljavanja znanstvenog sektora u protekcionističkom odnosu države prema znanstvenoj djelatnosti, odnosno financiranje iz budžetskih sredstava.

Može se pretpostaviti da to upućuje na snažnu orijentaciju prema etatizmu tj. zaštiti znanosti od strane države koja štiti znanstvenike od izlaganja tržišnom natjecanju i rizicima.

Tri skale općih vrijednosti formirane nakon eksplorativne faktorske analize 37 čestica različitih vrijednosnih orijentacija. Ispitanici su označili stupanj slaganja sa svakom tvrdnjom na skali od 1 do 5 gdje 1 označava potpuno slaganje a 5 potpuno neslaganje. Faktorskom analizom (metodom principijelnih komponenti i varimax rotacijom) ekstrahirana su 4 faktora a broj čestica reduciran je na 15 . Četiri faktora su reducirana na tri dimenzije zbog zasićenosti četvrtog faktora samo jednom česticom na temelju kojih su konstruirane tri skale općih vrijednosti. Za provjeru koeficijenta konzistentnosti skala korišten je Cronbach's Alfa test nakon kojeg su izostavljene 2 čestice da bi podigli vrijednost koeficijenta Alfa (Tablica 7). 
Tablica 6.

Faktorska solucija za vrijednosne orijentacije

\begin{tabular}{|c|c|c|c|c|}
\hline \multirow{2}{*}{ Vrijednosne orijentacije } & \multicolumn{4}{|c|}{ Komponente } \\
\hline & 1 & 2 & 3 & 4 \\
\hline Seljak je najpouzdaniji oslonac našeg naroda & .542 & .187 & -.449 & .419 \\
\hline Radnik je nosilac našeg gospodarskog razvoja & .499 & .123 & -.235 & .614 \\
\hline $\begin{array}{l}\text { Hrvatska bi trebala ograničiti uvoz stranih proizvoda radi zaštite domaćeg } \\
\text { gospodarstva }\end{array}$ & .814 & -.041 & .057 & -.105 \\
\hline Strancima ne bi trebalo dopustiti kupovanje zemljišta u Hrvatskoj & .720 & -.093 & -.073 & -.248 \\
\hline $\begin{array}{l}\text { Velike međunarodne kompanije cine sve veću štetu lokalnim } \\
\text { kompanijama u Hrvatskoj }\end{array}$ & .770 & .035 & .071 & -.127 \\
\hline Međunarodne organizacije oduzimaju hrvatskoj vladi previše ovlasti & .725 & -.002 & .152 & -.241 \\
\hline $\begin{array}{l}\text { Sve veća izloženost stranim filmovima i glazbi štetna je za nacionalnu } \\
\text { kulturu }\end{array}$ & .569 & .008 & -.252 & .071 \\
\hline $\begin{array}{l}\text { Država treba imati vodeću ulogu u ukupnom financiranju znanosti i } \\
\text { istraživanja }\end{array}$ & .115 & .055 & .762 & .071 \\
\hline Država treba imati vodeću ulogu u poticanju poduzetništva & .255 & .310 & .562 & .476 \\
\hline $\begin{array}{l}\text { Vlada treba definirati ulogu znanosti u društvenom i gospodarskom } \\
\text { razvitku }\end{array}$ & .020 & .246 & .571 & .241 \\
\hline Slobodno tržište čini dostupnima proizvode veće kvalitete & -.493 & .213 & -.193 & .374 \\
\hline $\begin{array}{l}\text { Znanje treba komercijalizirati - da bi se oslobodio ljudski kreativni } \\
\text { potencijal }\end{array}$ & -.041 & .815 & -.172 & -.064 \\
\hline Znanje treba komercijalizirati - da bi se ubrzao razvoj Hrvatske & .014 & .910 & -.008 & -.239 \\
\hline $\begin{array}{l}\text { Znanje treba komercijalizirati - da bi Hrvatsko gospodarstvo bilo } \\
\text { kompetitivno }\end{array}$ & -.053 & .878 & .042 & -.253 \\
\hline Poduzeća trebaju financirati inovacije i tehnologijska istraživanja & -.018 & .614 & -.158 & .038 \\
\hline$\%$ tumačenja varijance & 23.284 & 19.379 & 11.154 & 8.406 \\
\hline
\end{tabular}


Tablica 7.

Opće vrijednosne orijentacije

\begin{tabular}{|c|c|c|}
\hline & $\begin{array}{c}\text { Cronbach's } \\
\text { Alpha }\end{array}$ & $\begin{array}{c}\text { Aritm. } \\
\text { sredina }\end{array}$ \\
\hline $\begin{array}{l}\text { Skale tradicionalizma i anti globalizma } \\
\text { Seljak je najpouzdaniji oslonac našeg naroda } \\
\text { Radnik je nosilac našeg gospodarskog razvoja } \\
\text { Hrvatska bi trebala ograničiti uvoz stranih proizvoda radi zaštite domaćeg } \\
\text { gospodarstva } \\
\text { Strancima ne bi trebalo dopustiti kupovanje zemljišta u Hrvatskoj } \\
\text { Velike međunarodne kompanije cine sve veću štetu lokalnim kompanijama u } \\
\text { Hrvatskoj } \\
\text { Međunarodne organizacije oduzimaju hrvatskoj vladi previše ovlasti } \\
\text { Sve veća izloženost stranim filmovima i glazbi štetna je za nacionalnu kulturu }\end{array}$ & .812 & 3,0666 \\
\hline $\begin{array}{l}\text { Skala komercijalizacije znanja } \\
\text { Znanje treba komercijalizirati: - da bi se oslobodio ljudski kreativni potencijal } \\
\text { Znanje treba komercijalizirati: - da bi se ubrzao razvoj Hrvatske } \\
\text { Znanje treba komercijalizirati: - da bi Hrvatsko gospodarstvo bilo kompetitivno }\end{array}$ & .887 & 4,3103 \\
\hline $\begin{array}{l}\text { Skala etatizma } \\
\text { Država treba imati vodeću ulogu u ukupnom financiranju znanosti i istraživanja } \\
\text { Država treba imati vodeću ulogu u poticanju poduzetništva } \\
\text { Vlada treba stimulirati partnerstvo znanstvenog i gospodarskog sektora } \\
\text { Vlada treba definirati ulogu znanosti u društvenom i gospodarskom razvitku } \\
\text { Vlada treba rješavati probleme u upravljanju i organizaciji znanosti }\end{array}$ & .632 & 3,9479 \\
\hline
\end{tabular}

Konačno, analiza povjerenja u institucije pokazuje da ispitanici ponajviše vjeruju u znanstveni i obrazovni sustav dok vrlo malo vjeruju vladi, državnoj administraciji, sudstvu i političkim strankama (Tablica 8). Pomanjkanje povjerenja naših ispitanika (voditelja tehnologijskih projekata) u javne institucije i političare ukazuje na manjak socijalne kohezije među akterima inovacijskog sustava čiji su oni značajan segment.

Tablica 8.

Povjerenje u institucije - Koliko povjerenja imate u sljedeće institucije?

\begin{tabular}{|l|c|c|c|c|c|c|c|}
\hline & Nimalo & Ne puno & Osrednje & Puno & $\begin{array}{c}\text { Jako } \\
\text { puno }\end{array}$ & $\begin{array}{c}\text { Aritmetička } \\
\text { sredina }\end{array}$ & $\begin{array}{c}\text { Stand. } \\
\text { dev. }\end{array}$ \\
\hline Znanost & 0 & 6 & 25.6 & 50.4 & 17.9 & 3.8 & 0.801 \\
\hline Obrazovni sustav & 0.8 & 7.6 & 39.8 & 42.4 & 9.3 & 3.52 & 0.803 \\
\hline Vojska & 6 & 11.2 & 50 & 25.9 & 6.9 & 3.16 & 0.932 \\
\hline Zdravstvo & 2.6 & 18.8 & 42.7 & 33.3 & 2.6 & 3.15 & 0.843 \\
\hline Policija & 4.3 & 25.9 & 47.4 & 19 & 3.4 & 2.91 & 0.87 \\
\hline Vlada & 6.9 & 26.7 & 44 & 19 & 3.4 & 2.85 & 0.926 \\
\hline Javna uprava & 16.4 & 42.2 & 35.3 & 4.3 & 1.7 & 2.33 & 0.863 \\
\hline Sudstvo & 35.9 & 39.3 & 21.4 & 1.7 & 1.7 & 1.94 & 0.893 \\
\hline Političke stranke & 36.8 & 42.7 & 18.8 & 0.9 & 0.9 & 1.86 & 0.808 \\
\hline
\end{tabular}


Također ovo opće nepovjerenje u vladu i političke institucije upućuje na ograničene mogućnosti državne uprave da kroz programe javne politike kao što je TEST program mobilizira širi krug sudionika. Osim toga, može se pretpostaviti da nepovjerenje u vladu kod mnogih izaziva otpor prema bilo kojem od ovakvih programa i prvenstveno generira pitanja o njihovoj korumpiranosti, a manje o razlozima i svrsi.

\section{Zaključak}

Socijalna evaluacija TEST programa kroz analizu namjeravanih i nenamjeravanih posljedica ukazala je na niz prepreka u ostvarivanju inovacijske politike koje dovode do niske razine uključivanja poduzeća u program i niske razina komercijalne iskorištenosti rezultata projekata. Većina projekata uhvaćena je u "retrogradno kolo" koje kreće od znanstvene ideje i nakon pokušaja tehnološke primjene ili komercijalizacije, vraća se svojim polazištima, tj. rezultati istraživanja ponovo se koriste za znanstvene projekte.

Zamjena tehnoloških rezultata i očekivanih ekonomskih učinaka sa zapravo znanstvenim rezultatima, karakteristična je za većinu projekata i ukazuje, stoga, na postojanje strukturnih i sistemskih nedostataka inovacijskog sustava. Ti nedostaci identificirani su u samom dizajnu programa TEST (greške upravljanja programom od strane administracije), nedostatku socijalnog kapitala i u gospodarskom okruženju koje pati od manjka interesa za inovacije i suradnju s znanstvenim sektorom.

Možemo zaključiti slijedeće:

- najveći doprinos TEST-a je uvođenje organizacijskih i kulturoloških novina u standardnu znanstvenu politiku (orijentacija istraživanja ka primjeni, formiranje Tehnologijskog vijeća, nov način prijave, praćenja i evaluacije projekata) tj. stvaranje baze za inovacijsku politiku koja se prakticira u Europskoj uniji;

- značajan doprinos istraživačkog sektora gospodarskom razvoju rijetko se ostvaruje kroz male i "individualizirane" projekte, osim izuzetno TEST je i dalje potreban kao poticanje S-I suradnje i razvojnih istraživanja;

- korištenje istraživanja u gospodarskom razvoju traži tehnološki kompetentna poduzeća kojih u Hrvatskoj ima malo;

- naglasak HIS-a u Hrvatskoj treba biti jačanje proizvodne i inovativne sposobnosti poduzeća. Činjenica da su sektori temeljeni na R\&I za sada su izgubili bitku ukazuje na potrebu za promjenom strategije;

- uključivanje sveučilišta i instituta u gospodarski razvoj realnije je kroz šire razvojne platforme vođene konkretnim gospodarskim interesima tj. kroz umrežavanje institucija u zajedničke strateške projekte. Možda su upravo klasteri moguće rješenje te problematike koje ce polučiti poželjnije rezultate stremljenja inovacijske politike u Hrvatskoj;

- uloga vlade Republike Hrvatske u cijelom procesu je presudna jer tehnološki razvoj valja biti nacionalni projekt stoga je jedino uz njezinu zainteresiranu i proaktivnu uključenost moguće proizvesti željeni učinak. 
Konačno, postojanje strukturnih grešaka u sustavu dovodi u pitanje postojeći koncept inovacijske politike koja se temelji na "science-push" modelu, odnosno na znanstvenom inputu umjesto na potrebama gospodarstava. Čini se da je sadašnja inovacijska politika jednostavno krivo orijentirana isključivo na transformaciju rezultata istraživanja u nove tehnologije i poduzetničke projekte, dok je glavni izazov upravo suprotan: kako poduzetništvo zainteresirati za inovacije i ulaganje u istraživanja. Stoga se čini da parcijalne promjene ili uvođenje novih programa neće bitno utjecaji na promjene u gospodarstvu i uspješnost poduzetnih mjera, već je potreban temeljit zaokret u inovacijskoj politici, od one isključivo temeljene na znanstvenim istraživanjima do one temeljene na postojećim tehnološkim sposobnostima poduzeća i njihovom jačanju. Novi modeli inovacijske politike kao dualni (Xibao, 2009.) ili blizanački (twin) (Tylecote, 2006.) inovacijski sustavi koji kombiniraju regionalne inovacijske sustave i razvoj klastera s inovacijama temeljnim na znanju vrijedni su razmatranja. Donekle su vrata takvim sustavima otvorena IPA programom Europske unije koji snažno podržava regionalni razvoj. Isto tako, valja razmotriti mogućnosti i domete primjene inovacijske politike temeljene na potrebama (deman-driven) (Cunningham, 2009.) u Hrvatskoj.

\section{Literatura}

Arnold, E. (2004). Evaluating research an innovation policy: a systems world needs a systems evaluation. Research Evaluation, 13(1):3-17.

Carlsson, B. (2006). Internationalization of innovation systems: A survey of the literature. Research Policy, 35:56-57.

Cunningham, P. (2009). Demand-side Innovation Policies Policy Brief No. 1 (2009). Manchester Institute of Innovation Research. University of Manchester. February 2009.

Edquist, C. (1997). Systems of Innovation Approaches - Their Emergence and Characteristics, u: C. Edquist (Ur.). Systems of innovation - Technologies, institutions and organizations. London: Pinter Publishers/Cassell Academic.

Furman, J. L.; Porter, M. E. i Stern S. (2002). The determinants of national innovative capacity. Research Policy, 31:899-933.

Guy, K. (2003). Assessing RTD program portofolios int he European Union, u: Shapira. P. i Kuhlmann, S. (Ur.). Learning from science and technology policy evaluation. Edward Elgar Publishing Limited, UK i USA. 1174-204.

Kline S. J., Rosenberg, N. (1986). An overview of innovation, u: Landau i Rosenberg (Ur.). The positive sumstrategy, Harnessing technology for economic growth. Washington, DC: National Academy Press. 275-306.

Kuhlmann, S. (2003). Evaluation as a source of "strategic intelligence", u: Shapira. P. i Kuhlmann, S. (Ur.). Learning from science and technology policy evaluation. Edward Elgar Publishing Limited, UK i USA. 352-381.

Kuhlmann, S. (2006). Evolution of research evaluation. Lecture on seminar: RED Evaluation Course 2006. University of Twente, The Netherlands, December 2006.

MZT (2002). Program hrvatskog tehnologijskog razvitka (HITRA). Zagreb: Ministarstvo znanosti i tehnologije. Zbirka programskih dokumenata.

Lundvall, B. A i Borras, S. (1997). The globalizing learning economy: Implications for innovation policy. Report based on contributions from seven projects under TSER Program. DG XII, Commission of the European Union. 
North, D. C. (2003). Institucije, institucionalna promjena i ekonomska uspješnost. Zagreb: Masmedia.

Merton, R. K. (1936). The Unanticipated Consequences of Purposive Social Action. American Sociological Review, 1(6):894-904.

Mytelka, L. K., Smith, K. (2002). Policy Learning and Innovation Theory: An interactive and Co-evolving Process. Research Policy, 31:1567-1479.

Nelson, R. R. and Winter S. G. (1982). An evolutionary theory of economic change. The Belknap Press of Harvard University Press. 437.

OECD-EUROSTAT(2005). Oslo Manual: Guidlines for collecting and interpreting innovation dana. Third edition, OECD / European Communities.

Perrin, B. (2002). How to - and How Not to - Evaluate Innovation. Evaluation, Vol 8(1):1328.

Pisk, K. (2001). Suradnja znanosti i gospodarstva, izlaganje na skupu: Tehničke znanosti za brvatsko gospodarstvo. Peta multidisciplinarna konferencija. Akademija tehničkih znanosti Hrvatske i Hrvatsko društvo za sustave. Zagreb: 14. i 15. lipnja, 2001.

Rip, A. (2003). Societal challenges for R\&D evaluation, u: Shapira. P. i Kuhlmann, S. (Ur.). Learning from science and technology policy evaluation. Edward Elgar Publishing Limited, UK i USA. 32-54.

Risović, S. (2008). Primjena TEST programa u poslovnom sektoru. Znanstveni skup: Inovacijsko društvo i tehnološki razvoj. Zagreb: 24. travnja, 2008. CROSS i HGK.

Sharif, N. (2006). Emergence and development of the national innovation systems concept. Research policy, 35:745-766.

Švarc, J. (2004). Innovation policy in Croatia: the first 10 years, u: Proceedings of the 65th Anniversary Conference of the Institute of Economics. Zagreb: Institute of Economics.

Švarc, J. (2006). Socio-political factors and the failure of innovation policy in Croatia as a country in transition. Research Policy, 35(1):144-159.

Švarc, J. (2009). Hrvatska u društvu znanja: Prijepori i perspektive inovacijske politike. Zagreb: Školska knjiga.

Švarc, J. (2011). "Does Croatian national innovation system (NIS) follow the path towards knowledge economy?". Int. J. Technology Transfer and Commercialisation, 10(2):131151.

Tylecote, A. (2006). Twin innovation systems, intermediate technology and economic development: history and prospect for China. Innovation: Management, Policy \& Practice, $8(1 / 2): 62-83$.

Županov, J. (2001). Industrijalizirajuća i deindustrijalizirajuća elita u Hrvatskoj u drugoj polovici 20. stoljeća, u: Čengić, D. i Rogić, I. (Ur.). Upravljačke elite i modernizacija. Zagreb: Institut društvenih znanosti "Ivo Pilar".

Xibao, L. (2009). China's regional innovation capacity in transition: An empirical approach. Research Policy, 38:338-357. 
Original scientific work

\author{
Jadranka ̌́varc \\ Institute of Social Sciences Ivo Pilar \\ jadranka.svarc@pilar.hr \\ Juraj Perković \\ Institute of Social Sciences Ivo Pilar \\ juraj.perkovic@pilar.hr \\ Jasminka Lažnjak \\ Faculty of Humanities and Social Sciences in Zagreb, \\ Department of Sociology \\ jlaznjak@ffzg.hr
}

\title{
The Social Evaluation of the Croatian Innovation System Based on a Test Programme
}

\begin{abstract}
The paper presents selected results of the social evaluation of the Croatian innovation system (HIS) based on the thesis that, in Croatia, we can talk about the systemic failures of the innovation system, which leads to backwardness in technology and competitiveness.
\end{abstract}

The aim of research was to explore barriers to achieving the goals of the first innovation programme focused on supporting the technological projects (TEST programme) and, based on these findings, to figure out the systemic deficiencies of the whole innovation system.

The research was conducted by a questionnaire survey targeted at the leaders of the TEST projects and examines their attitudes towards a range of dimensions of the programme which are essential components of social evaluation of this segment of the innovation policy.

Currently, there is lack of evaluations that would assess the role and impact of innovation programmes for science and technology policy in relation to socio-cultural surroundings and historical heritage in which authors find their motive for such an investigation.

The study found that implementation of TEST resulted, besides intended consequences, in variety of unintended and failed consequences which change the programme focus from research commercialization, as the main goal, into generating scientific results that mostly serve the needs of the scientists for continuation of their scientific projects. Institutional deficits of the formal and informal character, followed by the broader socio-cultural context, are found to be among main drivers of unintended and failed consequences. The paper 
concludes that the most of the projects were caught in sort of a "backward loop" that moves from the scientific ideas and after an attempt of technological application and commercialisation returned to their starting points - the application of scientific appliance. Although TEST brought many organizational and cultural novelties to scientific policy, results suggest a need for thorough reform of innovation policy - from one based exclusively on scientific research into one focused on existing needs and capacities of companies.

Key words: innovation system, Croatia, social evaluation, innovation policy, indented and unintended consequences. 